\title{
The stock market performance of the central banks of Belgium and Japan
}

\author{
Lawrence G. Goldberg ${ }^{\mathrm{a}, *}$, Rezaul Kabir ${ }^{\mathrm{b}, \mathrm{c}}$

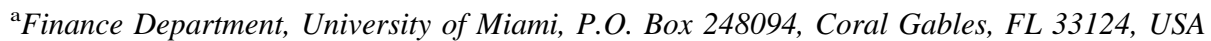 \\ ${ }^{\mathrm{b}}$ Department of Finance, University of Tilburg, P.O. Box 90153, 5000 LE Tilburg, The Netherlands \\ ${ }^{\mathrm{c}}$ University of Antwerp, Belgium
}

Received in revised form 23 April 2001; accepted 19 July 2001

\begin{abstract}
Most central banks issue stock that is held by the government and/or commercial banks and is not tradable. In contrast, stocks of the central banks of Belgium and Japan are traded on the Brussels and Tokyo stock exchanges. The purpose of the paper is to examine this unique phenomenon of stock market valuation of central banks. Our analysis shows that shares of these two central banks have performed poorly. We also investigate the factors affecting central bank stock returns and find that the stock market return is the only statistically significant determinant. Neither the assets held by the central bank nor the country's macroeconomic factors show strong and stable relationships with central bank stock returns. An event study using recent data from Japan shows that the effect of certain macroeconomic events on the value of the Bank of Japan stock is statistically insignificant. () 2002 Elsevier Science Inc. All rights reserved.
\end{abstract}

JEL classification: E58; G20; N20

Keywords: Central bank; Stock market; Valuation; Performance

\section{Introduction}

Most central banks issue stock that is held by the government and/or commercial banks and is not tradable. In contrast, the stock of the central banks of Belgium (the National Bank

* Corresponding author. Tel.: +1-305-284-1869; fax: +1-305-284-4800.

E-mail address: lgoldberg@miami.edu (L.G. Goldberg). 
of Belgium, hereafter called NBB) and of Japan (the Bank of Japan, hereafter called BOJ) are traded on the Brussels and Tokyo stock exchanges, respectively. The Belgian government holds half of the Belgian central bank's stock while private and institutional investors hold the other half. Since the BOJ was modeled on the NBB, the Japanese government holds more than half of the Bank of Japan stock and the rest is also distributed among individuals, financial and other institutions.

Even though investors have been buying the central bank shares for decades, they have no influence on the policies of either central bank. The non-governmental shareholders have almost no rights that typically exist in all other public limited corporations. Why do investors regularly buy or sell central bank stocks? Do they receive adequate returns? Why is some of the stock of central banks traded in the open market? What affects the value of this stock and how is this related to the rationale for the public trading of a central bank's stock? These are some questions that we attempt to address in this paper in order to obtain a better understanding of central banks.

The remainder of the paper is organized as follows. The next section briefly discusses the history and the organization of the central banks of Belgium and Japan. The third section presents the hypotheses and the fourth section describes the data. The fifth section presents empirical evidence on the performance of central bank stocks. Section six investigates the factors affecting the changes in value of central bank stocks. The section also reports the results from an event study examining the stock market reaction of Japanese central bank shares to macroeconomic announcements. Conclusions are drawn in the final section.

\section{History and organization}

\subsection{The central bank of Belgium ${ }^{1}$}

Until the early $19^{\text {th }}$ century, one influential company, Société Générale, controlled the whole credit system in Belgium. With the establishment of the independent state of Belgium in 1830 , this private company received certain rights, and its relationship with the State had the appearance of that of central bank of a country. In order to diminish the role of Société Générale, a new private bank, the Bank of Belgium, was created in 1835. The Belgian government transferred the function as cashier of the treasury from Société Générale to the Bank of Belgium. The financial crises during the 1830s and 1840s weakened the institutions and reduced the confidence of the general public in both of these two institutions.

This led the government to establish the National Bank of Belgium in May 1850 as a public limited company. Interestingly, private individuals, firms and utilities, but not the government subscribed to the shares of the Bank and trading of the shares of the NBB took place from the beginning. ${ }^{2}$ Although bank notes issued by Société Générale and Bank of Belgium had legal tender status at that time, those issued by the NBB became legal tender only in 1873 .

The management of the Bank is in the hands of the Governor and the Board of Directors. The Governor is appointed, suspended and dismissed by the King (in practice, by the government). Although appointed by the King, the governor and the directors are expected 
to make all decisions independently. The government designates a commissioner who attends Board's meetings and supervises the operations of the Bank. Although the government kept the activities of the Bank under its supervision, the independence of the Bank was specified by statutory measures. It should be noted here that the supervision of financial institutions in Belgium is the responsibility of a separate institution-the Banking and Finance Commission, which was created in 1935.

Following World War II, there was a debate on the desirability of nationalization in Belgium that was similar to debates in many other countries. A compromise decision was reached. The number of shares was doubled in 1948 and all new shares, registered and nontransferable, were given to the State. This ended almost 100 years of existence of the National Bank of Belgium as a $100 \%$ privately owned enterprise. The remaining $50 \%$ shares are still owned by private and institutional investors, and the stock remains listed on the Brussels Stock Exchange.

There are indications that shareholders of the NBB are numerous. At the end of 1998, there were as many as 115 registered non-governmental shareholders who held only $3 \%$ of the central bank's total shares. The rest (47\%) of the shares are bearer, and therefore, their identity is not known. Although each share has one vote, the government with its $50 \%$ share holds the decisive votes. The private shareholders have no power in making monetary policy decisions or in appointing the Governor or other members of the Board of Directors. Thus, the private and institutional shareholders can benefit only when the capital market increases its valuation of the stock of the central bank. The charter of the NBB lays down the procedure for distributing profits among shareholders, but only after making a substantial payment to the State. As of Dec. 1998, each NBB share was priced at about 1850 Euros but by the beginning of 2001 had fallen to around 1600 Euros. The average annual dividend yield has been between three and four percent.

\subsection{The central bank of Japan}

In the late 1860s Japan made major efforts to modernize the country's political, economic, and social institutions. ${ }^{3}$ Missions were sent to study American and European banking systems. In 1872 Japan established a national banking system patterned after the American system initiated in 1863. In response to the inflationary financing of a rebellion against the Meiji government in 1877, the Bank of Japan was established in October of 1882. Since the United States did not have a central bank at this point, the Japanese government looked to Europe to find a model for its new central bank. Though the new central bank was modeled after the National Bank of Belgium, it developed into a very different type of institution (Goodhart, 1991). Whereas the National Bank of Belgium was independent from political interference, the Bank of Japan was from the outset under the direction of the Ministry of Finance. The original legislation was revised in 1942 to incorporate wartime conditions and this has remained essentially the current structure. After considerable debate, in 1997 the Japanese parliament increased the independence of the Bank of Japan in setting interest rates and in internal operation of the Bank. However, the Bank of Japan still does not have the autonomy from the central government enjoyed by many western central banks.

There are several other important characteristics of the Japanese central bank. It plays a 
minor role in the regulation and supervision of the financial system. Large banks borrow from the Bank at below market rates and then lend in turn to smaller banks. The BOJ supervises foreign exchange activities but does not actually undertake them.

The Japanese government owns $55.1 \%$ of its stock and the rest is tradable. ${ }^{4}$ Stock ownership of the Bank as of May 1, 1998 was divided as follows: individuals (36.7\%); financial institutions $(4.0 \%)$; public institutions $(0.55 \%)$; and other corporations $(3.5 \%)$. The stockholders can not vote on matters and there are no stockholder meetings. The BOJ stock traded at around 100000 Yen at the end of 1998 but had fallen to around 65000 Yen at the beginning of 2001. The dividend to earnings ratio must be less than 5 percent. In the event of bankruptcy, the stockholders can not claim the assets of the Bank of Japan.

\section{Hypotheses}

We model central bank stock return assuming a linear relationship in the following way: Central bank stock returns $=\mathrm{f}$ (Stock market return, Bank-specific factors, Macro-economic factors).

Like any other stock, we, first of all, expect that central bank stock returns are positively related to the returns of the stock market. If the stock market performs well, the central bank's stock is also expected to perform well. If the market declines, its stock price declines too. In addition, we hypothesize that two types of factors, bank-specific factors and macroeconomic factors, are related to the central bank's stock returns. The former group consists of the assets held by the central bank (predominantly gold reserves and foreign currency reserves) while the latter contains variables like national output, price level, money supply, unemployment rate, discount rate and exchange rates.

The growth in assets of the central bank or its main components is expected to have a positive influence on the stock price because it indicates higher earnings power and a stronger central bank position. As for the macroeconomic variables, it is well known that central banks have several roles in the economy. The most important role is the design and administration of monetary policy. By affecting interest rates and/or the money supply, central banks are charged with maintaining price stability (low inflation), and thus, a healthy economy. Consequently, the central bank is generally well regarded when the economy is strong. This public attitude towards the central bank might be reflected in the stock price of the bank. If the economy is doing poorly, which is reflected in lower national output and rising unemployment, there may be attempts to reorganize/abolish the central bank or to change its character. This may lead to decreases in the value of the central bank stock. A higher discount rate restrains the economy and thus the discount rate should be negatively related to the central bank stock price. Increases in the money supply stimulate the economy and might thus have a positive effect on the stock price. However, too great a stimulus could increase inflation, and this would have a negative impact on stock price. Therefore, the effect of the money supply is indeterminate. The performance of the currency of the country might also affect the public attitude towards the central bank, which in turn could affect the stock price.

In many countries the central bank is the primary regulator of financial institutions. The value of the central bank stock may then be affected by the performance of banks under its 
authority. However, several countries have removed bank regulatory powers from the central bank and given them to a separate bank regulator. This has most notably occurred recently in the United Kingdom, as the Bank of England is no longer the prime regulator of banks. For several decades, the central bank of Belgium has not been the primary regulator of the banking system. Therefore, we would not expect the Belgian central bank's stock performance to be influenced by the performance of the banking sector. The Bank of Japan has also never been the prime regulator and supervisor of Japanese banks. On the other hand, one can argue that the performance of commercial banks may serve as an indicator of a country's macroeconomic condition. This may be reflected in a positive relationship between profitability of commercial banks and central bank stock returns.

\section{Data}

A detailed data collection was possible for the central bank of Belgium, mainly due to cooperation from its staff. Annual stock prices of the central bank of Belgium are collected from 1854 until 1998 (stock price data for the first two years of the existence of the Bank are not available). End-of-year share prices and annual dividends are used to calculate total annual stock returns. We collect daily stock prices from Datastream from 1973 onwards. A price index on the Belgian stock market is available since 1921. For the first three decades this market index does not include dividends. We use market index data including dividends from 1951 onwards. ${ }^{5}$ For the more recent period (since 1973) we are able to collect data of a few more stock market indices from Datastream. These are: Datastream Belgian Bank Index, Bank Brussels Lambert 30 Stock Index, and Datastream Bel-20 Stock Index.

From the annual reports of the central bank of Belgium, we collect data on total assets held by the central bank and two of its principal components, namely gold reserves and foreign currency reserves. We also collect a wide variety of Belgian macroeconomic data like gross domestic product, industrial production, money supply, gold price, interest rate, discount rate, unemployment rate, inflation rate and exchange rates. Because of limitations on historical data availability regarding all of these variables, we are able to construct an annual data set for the period 1953-1998. In order to analyze relationships with commercial bank profitability, we collect annual data of average return on equity for all Belgian banks. These data are only available since 1975 .

We could not get historical data on the Bank of Japan for a long time period as we could for the Belgian central bank. Consequently, our analysis on BOJ is limited to publicly available data. In Datastream stock prices of Bank of Japan are available only since January 1991. We also collect data on four Japanese stock market price indices. These are: Nikkei 300, Nikkei 500, Nikkei Total Banking and MSCI Japan price indices.

We are unable to obtain bank-specific data such as total assets, gold and foreign currency reserves. Some Japanese macroeconomic data are reported in the International Financial Statistics published by the International Monetary Fund. Since only ten years of BOJ stock price data are available, we decided to use Japanese macroeconomic data on a monthly basis as it will allow us to have a larger number of observations. The use of monthly data, however, has some limitations like seasonal fluctuations and unavailability of data for many variables. 
Nevertheless, we are able to construct a monthly data set covering the period 1991-2000 and consisting of five variables: stock market return, money supply, discount rate, gold value and industrial production. In order to make a comparative analysis for the Belgian central bank, we also construct a similar monthly data set for Belgium. ${ }^{6}$

A stock market reaction analysis would enable us to check if macroeconomic announcements affect central bank stock returns. Therefore, we search for all news announcements involving the Bank of Japan from 1991 to 2000 in the Wall Street Journal Index and Lexis Nexis. ${ }^{7}$ We are able to identify 25 relevant monetary announcements during this time period. Similar databases do not exist for Belgium and, therefore, it was not possible for us to analyze Belgian macroeconomic announcements.

\section{Evidence on stock performance}

We calculate the cumulative annual stock return of the Belgian central bank back from 1854. We find that the stock has appreciated well over $1100 \%$ in the last one and a half centuries and that stock returns of the Bank were sometimes volatile. For example, during the $19^{\text {th }}$ century, the stock return was negative $(-5.6 \%)$ in 1859 and $(-11.4 \%)$ in 1872 while positive $(13.4 \%)$ in 1857 and $(13.8 \%)$ in 1879 . There was no official stock trading during July 1914-February 1919 due to the First World War, although shareholders of NBB continued to receive a constant amount of cash dividends. ${ }^{8}$ The stock of the central bank also suffered huge losses during the Great Depression period with a return of $-12.5 \%$ in 1931 and $-17.8 \%$ in 1932 , and after the Second World War with a return of $-18.5 \%$ in $1945,-22.4 \%$ in 1946 and $-9.5 \%$ in 1947 . But, these losses were quickly offset by relatively high stock returns during the succeeding years.

The cumulative returns obtained from investing in a stock, however, must be compared to a benchmark in order to take account of inflation and the general movement of equity prices. A comparison of the stock returns of NBB with that of the Belgian stock market is possible since 1921. Figure 1 presents the cumulative abnormal returns of NBB stock. The abnormal return is estimated by subtracting the return of the stock market from the central bank's stock return. We observe that until the end of World War II, the NBB stock is clearly outperformed by the market (even though the market returns are underestimated since they do not contain dividends). In subsequent years the NBB stock performed better than the market due to several years of extremely high NBB stock returns. But, the increased returns did not last long. As we can see from the figure, the cumulative abnormal returns remained negative in almost all years. The downward drift of NBB stock returns is clearly visible in the eighties and the nineties. We can, therefore, conclude that the stock of the Belgian central bank has not been performing well during the past few decades. Investors could have earned greater returns by investing in the market rather than from investing in this stock.

In order to perform a quantitative analysis, we calculate annual returns by decades for the $\mathrm{NBB}$, the market and government bonds. The mean and standard deviations of these returns for each decade are reported in Table 1. The average stock return of NBB is relatively low in the twenties and the thirties. NBB stock out-performs the market in the forties and the fifties. There is not a large difference in returns between NBB and the stock market in the 
Table 1

Return and risk of the central bank of Belgium

\begin{tabular}{|c|c|c|c|c|c|c|}
\hline \multirow[t]{2}{*}{ Period } & \multicolumn{2}{|c|}{ Central bank of Belgium } & \multicolumn{2}{|c|}{ Stock market } & \multicolumn{2}{|c|}{ Government Bonds } \\
\hline & $\begin{array}{l}\text { Average } \\
\text { return }\end{array}$ & $\begin{array}{l}\text { Standard } \\
\text { deviation }\end{array}$ & $\begin{array}{l}\text { Average } \\
\text { return }\end{array}$ & $\begin{array}{l}\text { Standard } \\
\text { deviation }\end{array}$ & $\begin{array}{l}\text { Average } \\
\text { return }\end{array}$ & $\begin{array}{l}\text { Standard } \\
\text { deviation }\end{array}$ \\
\hline $1921-1930$ & 0.055 & 0.271 & 0.149 & 0.352 & 0.051 & 0.007 \\
\hline $1931-1940$ & 0.031 & 0.266 & 0.072 & 0.453 & 0.043 & 0.003 \\
\hline $1941-1950$ & 0.111 & 0.258 & 0.054 & 0.285 & 0.042 & 0.003 \\
\hline $1951-1960$ & 0.201 & 0.258 & 0.128 & 0.199 & 0.051 & 0.005 \\
\hline 1961-1970 & 0.068 & 0.105 & 0.082 & 0.129 & 0.064 & 0.008 \\
\hline 1971-1980 & 0.066 & 0.084 & 0.050 & 0.152 & 0.087 & 0.014 \\
\hline 1981-1990 & 0.135 & 0.173 & 0.214 & 0.244 & 0.105 & 0.021 \\
\hline 1991-1998 & 0.147 & 0.133 & 0.206 & 0.174 & 0.071 & 0.015 \\
\hline
\end{tabular}

Stock returns are calculated based on annual stock price changes plus dividends. Market returns are calculated based on price changes of a stock market index. The stock market index values from 1951 onwards includes dividends.

following two decades. But, in the eighties and the nineties the market has again higher average returns than NBB. We also observe that NBB stock returns show relatively low volatility in the twenties and the thirties and also in the sixties and the seventies. Annual volatility of NBB stock returns increases in the eighties and nineties, but it is lower than the market volatility. The government bond return changes relatively little over the decades and also shows a considerably lower standard deviation within decades.

It is useful to compare NBB stock returns with more than one benchmark. Therefore, for the more recent period (since 1973) three additional indices are used, Datastream Belgian Bank Index, Bank Brussels Lambert 30 Stock Index, and Datastream Bel-20 Stock Index. The analysis of cumulative excess stock returns using all four benchmarks reveals that the stock of the central bank does not exhibit significant over- or under-performance during the initial years. There are high NBB stock returns since 1982, but these are much less when adjusted for index returns. Excess returns actually turn negative when compared to total returns earned from the stock market.

We also evaluate the performance of NBB stock returns on a risk-adjusted basis. For each month starting from January 1978, we estimate the alpha and the beta parameters of the simple Market Model using previous 60 months of data. The excess return of each month is estimated by subtracting the Market Model predicted return from the contemporaneous NBB stock return. With an estimated average beta of 0.64 it appears that the stock of the central bank is less risky than the market as a whole. In that case, the simple market adjusted excess returns (which assumes a beta equal to one) may bias the relative stock performance. The graphs of both market-adjusted and risk-adjusted abnormal returns are presented in Figure 2. We observe that, although the extent of under-performance of NBB stock is reduced, it is nevertheless present. The risk-adjusted stock returns are also negative. The finding of underperformance of the Belgian central bank stock is, therefore, robust.

To provide further insight into a central bank's stock market performance, we estimate both market-adjusted and risk-adjusted stock returns of the central bank of Japan. Market adjusted abnormal returns are defined as the BOJ stock return minus the return on the NIKKEI 500 index. Risk-adjusted abnormal stock returns are calculated from the Market 


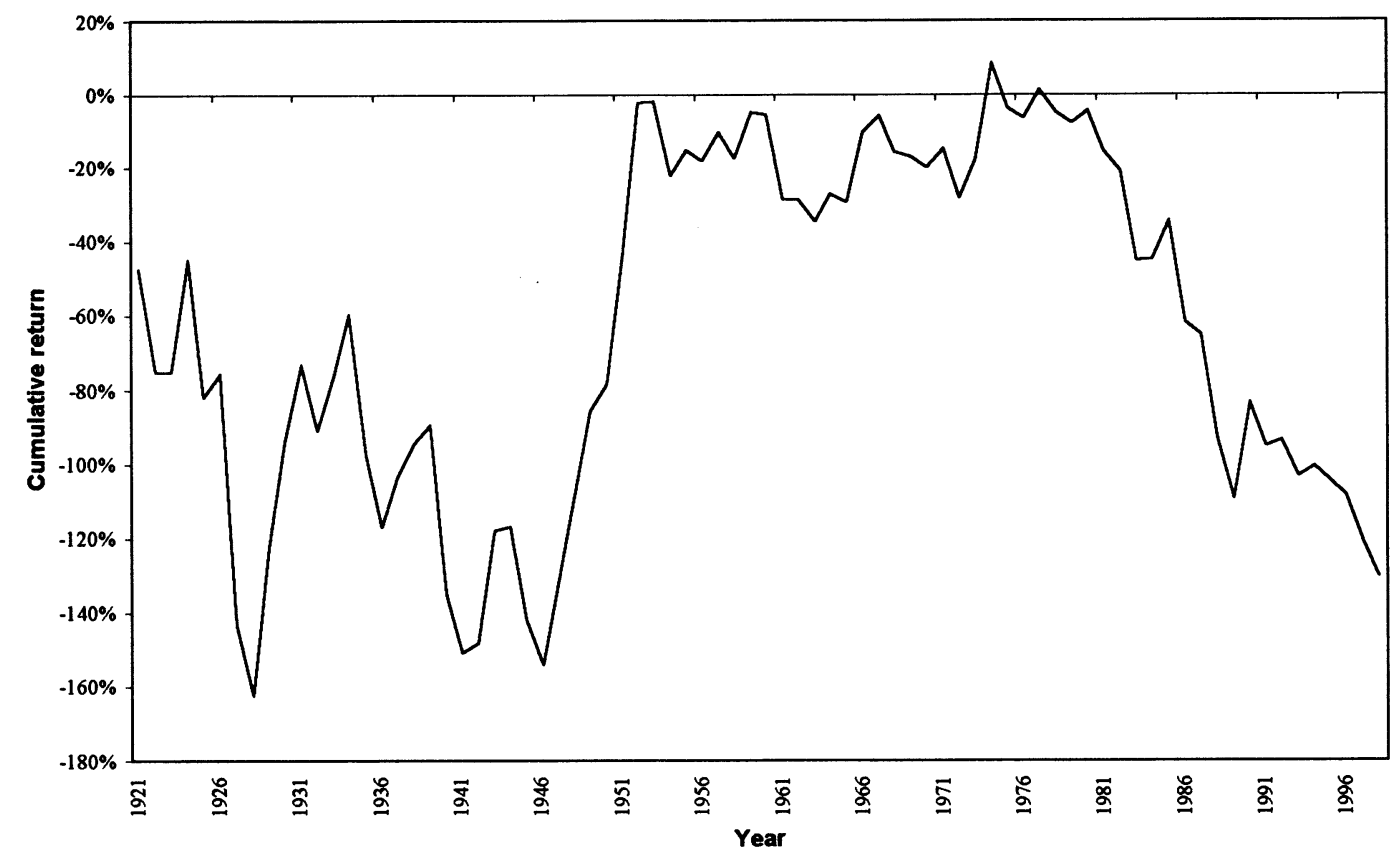

Fig. 1. Cumulative excess stock returns of the central bank of Belgium: 1921-1998. The figure depicts cumulative annual excess stock returns for the period 1921-98. Stock returns are calculated based on annual stock price changes plus dividends. Market returns are calculated based on price changes of a stock market index. The stock market index includes dividends from 1951 onwards. Excess stock returns are calculated after subtracting the stock market return.

Model where the model parameters are estimated using stock returns of the previous 60 months. As mentioned earlier, BOJ stock returns are available since 1991. Cumulative abnormal stock returns can, therefore, be calculated for the 1996-2000 period only. Figure 3 presents the results. For the sake of comparison, we also calculate cumulative excess stock returns of the Belgian central bank during the same time period and show the results in the figure.

We observe a clear underperformance of stocks of both central banks. The underperformance of BOJ is greater than that of NBB. The market adjusted CAR of the central bank of Japan during 1996-2000 is $-94 \%$, while the risk-adjusted CAR is $-53 \%$. A sharp decline of BOJ stock return appears to have taken place since 1999. A similar result holds for the central bank of Belgium. The market adjusted and risk-adjusted CAR of NBB is $-33 \%$ and $-25 \%$, respectively. Relatively poor stock performance has taken place predominantly in 1999 and 2000. Overall, the empirical evidence for both central banks shows that the investment of shareholders has not been profitable.

\section{Determinants of central bank stock returns}

To improve our understanding of the changes in central bank's stock returns, we now explain the return as a function of the return on the stock market, central bank variables and 


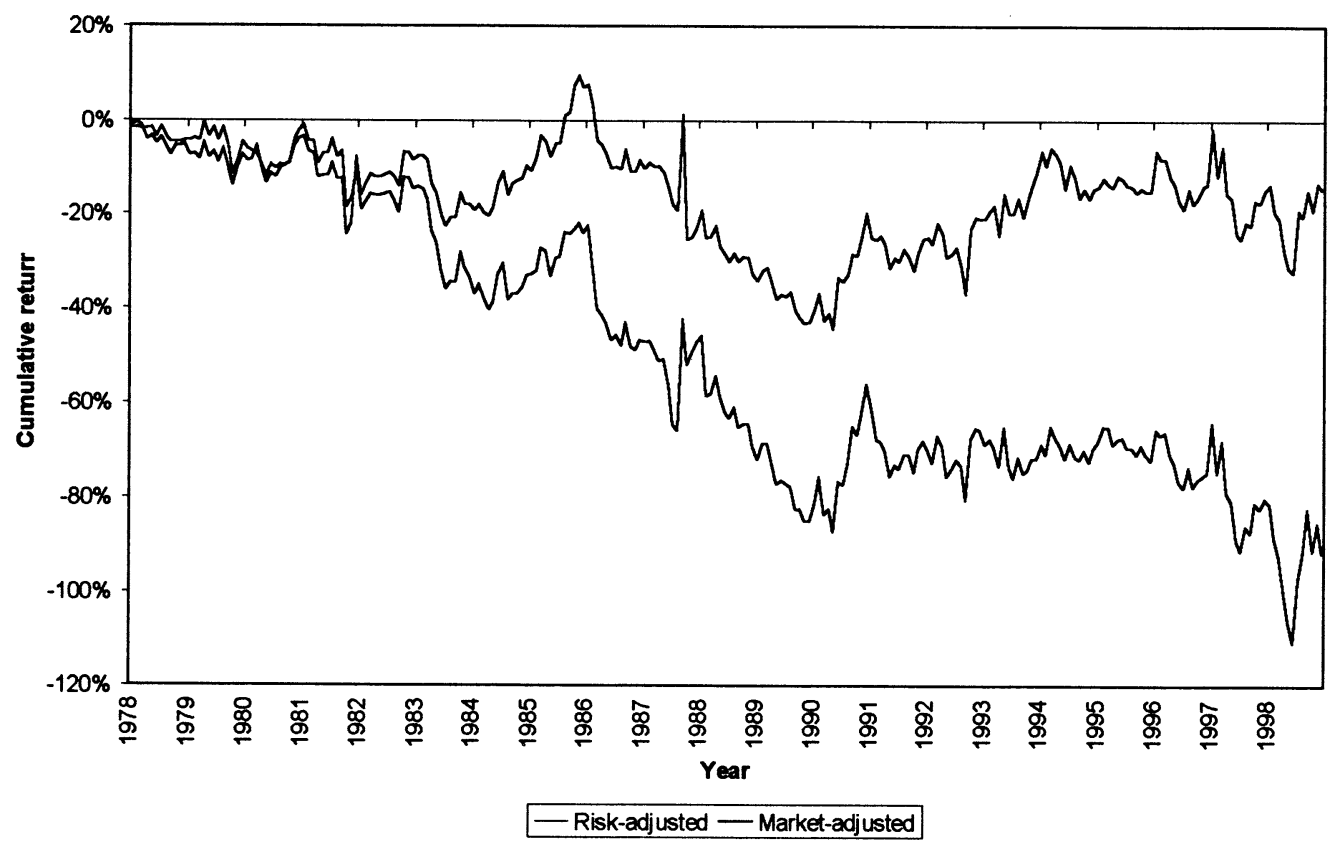

Fig. 2. Cumulative excess stock returns of the central bank of Belgium: 1978-98. The figure depicts risk-adjusted and market-adjusted cumulative monthly stock returns for the period 1978-98. Stock returns are calculated based on monthly stock price changes and include dividends. Market Model parameters are estimated using previous 60 months of data to calculate risk-adjusted returns. Monthly market-adjusted returns are estimated by subtracting total stock market return.

macroeconomic variables. For Belgium, an investigation of central bank variables and a large number of macroeconomic variables for a long time period (since 1953) can be obtained only by using annual data. For a shorter time period (since 1991) monthly data can be used for both Belgium and Japan, but only a few independent variables can be examined.

\subsection{Annual analysis}

We first investigate the determinants of central bank stock returns using the more comprehensive data set. The results of the regression analysis are presented in Table 2 . Model (1) suggests that the stock return of the central bank of Belgium has a statistically significant positive relationship with the return of the stock market. The regression coefficient is 0.54 with a t-statistic of 7.78 . The $\mathrm{R}^{2}$ value suggests that the stock market return explains 58\% of the total variation of NBB stock returns. The relationship between bankspecific factors and stock returns is examined in model (2). We find that the regression coefficient of growth rates in total assets of the central bank is statistically insignificant. Performing regressions using gold reserves and combined gold and foreign currency reserves as separate variables does not provide significant coefficients either. The finding is particularly interesting as it suggests that the assets held by the central bank have no contemporaneous relationship with its stock returns. 


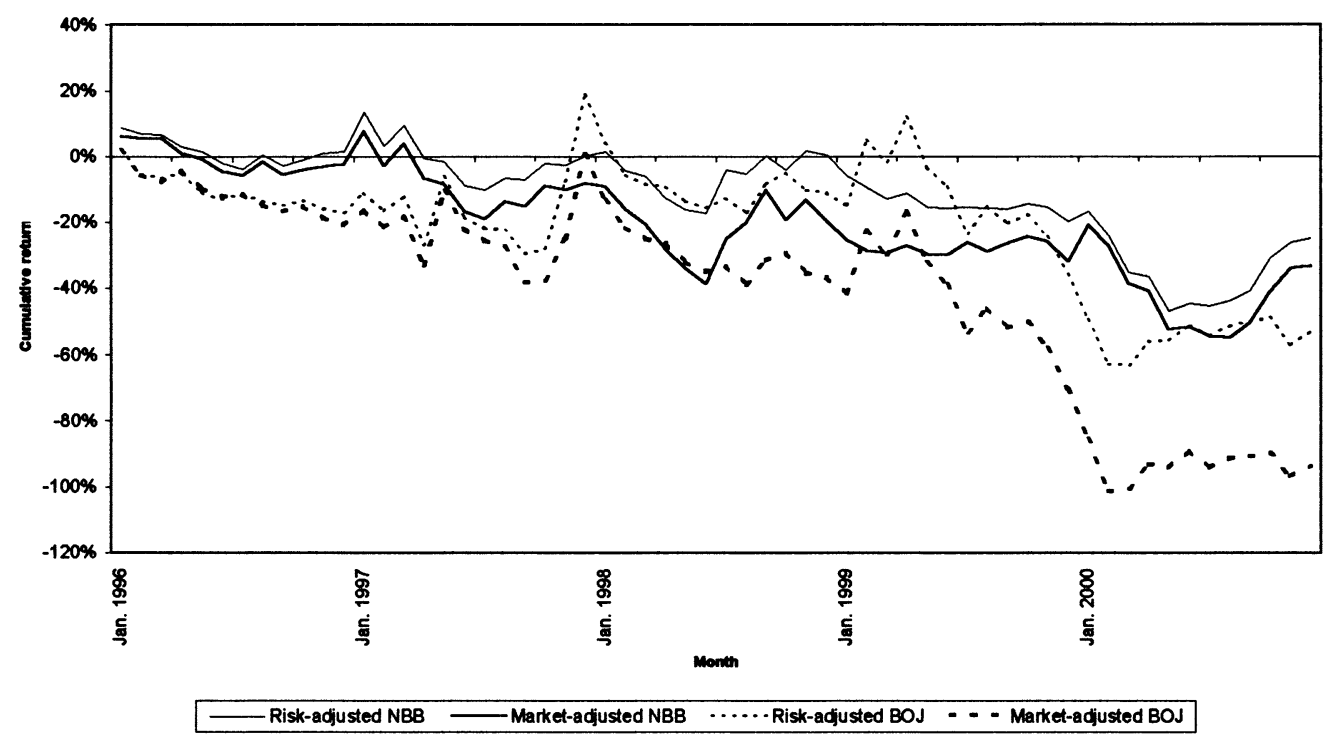

Fig. 3. Cumulative excess stock returns of the central banks of Belgium and Japan: 1996-2000. The figure depicts risk-adjusted and market-adjusted cumulative monthly stock returns of the central banks of Belgium (NBB) and Japan (BOJ) for the period 1996-2000. Stock returns are calculated based on monthly stock price changes and include dividends. Market Model parameters are estimated using previous 60 months of data to calculate risk-adjusted returns. Monthly market-adjusted returns are estimated by subtracting total stock market return.

Next, we analyze if macroeconomic variables show any relationship with central bank stock returns. We consider a large number of variables such as annual growth rates in gross domestic product, industrial production, balance of trade, money supply, gold price, government debt, inflation rate, discount rate, unemployment rate and exchange rates. First, we perform univariate analysis in the contemporaneous form. One can argue that information on several variables may be available to the stock market with some delay. This may lead to a non-contemporaneous relationship. To examine this, we also perform the analysis using lagged explanatory variables.

Since most of the regression coefficients are statistically insignificant, we do not report the results for each variable in Table 2 . We observe that the unemployment rate has a positive relationship with central bank stock returns (model 4). It appears that a high unemployment level may lead to an expansionary economic policy that benefits the central bank's stock price. Although the dollar exchange rate variable shows no significant relationship in the contemporaneous context (model 5), we observe that the lagged variable produces a significant positive coefficient. Lower values of the Belgian currency (i.e. higher dollar rate) may lead to increases in exports and reductions in imports that would stimulate the economy.

We now proceed to examine if these and other variables show significant relationships with central bank stock returns in the multivariate context. The multivariate analysis which controls for the simultaneous effect of different variables provides the strongest test of our hypotheses. Our results indicate that the only explanatory variable consistently significant at the $5 \%$ level in all regression models is the stock market return. Its coefficient remains almost 
Table 2

Determinants of central bank stock returns: annual analysis

\begin{tabular}{|c|c|c|c|c|c|c|}
\hline Explanatory variable & (1) & (2) & (3) & (4) & $(5)$ & (6) \\
\hline Stock market return & $\begin{array}{c}0.540 \\
(7.78)\end{array}$ & & & & & $\begin{array}{c}0.549 \\
(6.97)\end{array}$ \\
\hline Total assets growth rate & & $\begin{array}{c}-0.191 \\
(0.71)\end{array}$ & & & & $\begin{array}{c}-0.195 \\
(1.05)\end{array}$ \\
\hline Industrial production growth rate & & & $\begin{array}{c}0.045 \\
(0.09)\end{array}$ & & & $\begin{array}{c}0.206 \\
(0.61)\end{array}$ \\
\hline Unemployment rate & & & & $\begin{array}{c}0.685 \\
(1.82)\end{array}$ & & $\begin{array}{r}-0.127 \\
(0.42)\end{array}$ \\
\hline Dollar rate & & & & & $\begin{array}{c}0.284 \\
(1.33)\end{array}$ & $\begin{array}{c}0.051 \\
(0.34)\end{array}$ \\
\hline Intercept term & $\begin{array}{c}0.032 \\
(2.03)\end{array}$ & $\begin{array}{c}0.111 \\
(4.82)\end{array}$ & $\begin{array}{c}0.101 \\
(4.23)\end{array}$ & $\begin{array}{c}0.052 \\
(1.55)\end{array}$ & $\begin{array}{c}0.103 \\
(5.30)\end{array}$ & $\begin{array}{c}0.043 \\
(1.42)\end{array}$ \\
\hline (Adj.) R-sqr. & 0.58 & 0.01 & 0.02 & 0.07 & 0.04 & 0.54 \\
\hline
\end{tabular}

Univariate and multivariate regression where the stock return of the central bank of Belgium is used as the dependent variable. Annual data for the period 1953-1998 are used. The estimated regression coefficient is first mentioned beneath which the absolute value of the t-statistic is presented.

unchanged among all multivariate model specifications. We also find that the bank-specific and macroeconomic variables, in both contemporaneous and non-contemporaneous forms, do not have any statistically significant relationship with the central bank stock returns. The inclusion of these variables in regressions does not lead to any improvement in the explanatory power of the regression models. We present, as an example, the regression results from one multivariate test in Table 2, model (6). The stock market return variable has a regression coefficient of 0.55 with a t-statistic of 6.97 (which is highly significant). All other variables are statistically insignificant. The multivariate analysis thus fails to uncover any other significant determinants of stock returns of the central bank.

We also examine whether the performance of the banking sector can explain changes in the stock returns of the central bank. ${ }^{9}$ Even though the Belgian central bank does not regulate commercial banks, the performance of commercial banks may serve as an indicator of macroeconomic conditions. Although commercial bank profitability is positively related to the stock returns of the central bank, the regression coefficient is not statistically significant. We also find that bank profitability has no incremental relevance once the stock market return is used as an explanatory variable.

Overall, in explaining annual stock returns of the central bank of Belgium, we observe that the market return is significantly related to central bank stock returns in all regression models. It alone explains more than half of the total variation of central bank stock returns. Examining different bank-specific and macroeconomic variables, we find that these variables have no statistically significant relationship with stock return of the central bank. Our result, however, is not dissimilar to trying to explain the stock returns of any other company. It is very difficult, if not impossible, to trace certain economic factors that can significantly explain stock returns of a single firm. Much of the movement of an individual stock may be attributable to non-measurable variables, sentiment, and momentum. 
Table 3

Determinants of central bank stock returns: monthly analysis

\begin{tabular}{|c|c|c|c|c|c|c|}
\hline Explanatory variables & (1) & (2) & (3) & (4) & (5) & (6) \\
\hline \multicolumn{7}{|l|}{ Part A: Central Bank of Japan } \\
\hline Stock market return & $\begin{array}{c}0.904 \\
(7.04)\end{array}$ & & & & & $\begin{array}{c}0.704 \\
(5.50)\end{array}$ \\
\hline Money supply growth rate & & $\begin{array}{c}-0.012 \\
(0.06)\end{array}$ & & & & $\begin{array}{c}0.135 \\
(0.86)\end{array}$ \\
\hline Discount rate & & & $\begin{array}{c}0.249 \\
(0.44)\end{array}$ & & & $\begin{array}{c}0.120 \\
(0.27)\end{array}$ \\
\hline Gold value growth rate & & & & $\begin{array}{c}0.269 \\
(0.42)\end{array}$ & & $\begin{array}{c}-0.092 \\
(0.18)\end{array}$ \\
\hline Industrial production growth rate & & & & & $\begin{array}{c}0.790 \\
(2.21)\end{array}$ & $\begin{array}{c}0.546 \\
(1.58)\end{array}$ \\
\hline Intercept term & $\begin{array}{c}-0.009 \\
(1.17)\end{array}$ & $\begin{array}{c}-0.007 \\
(0.73)\end{array}$ & $\begin{array}{c}-0.011 \\
(0.83)\end{array}$ & $\begin{array}{r}-0.007 \\
(0.72)\end{array}$ & $\begin{array}{r}-0.012 \\
(1.410\end{array}$ & $\begin{array}{c}-0.017 \\
(1.53)\end{array}$ \\
\hline (Adj.) R-sqr. & 0.29 & 0.00 & 0.00 & 0.00 & 0.04 & 0.23 \\
\hline \multicolumn{7}{|l|}{ Panel B: Central Bank of Belgium } \\
\hline Stock market return & $\begin{array}{c}0.492 \\
(5.60)\end{array}$ & & & & & $\begin{array}{c}0.484 \\
(5.41)\end{array}$ \\
\hline Money supply growth rate & & $\begin{array}{c}0.027 \\
(0.19)\end{array}$ & & & & $\begin{array}{c}0.070 \\
(0.56)\end{array}$ \\
\hline Discount rate & & & $\begin{array}{c}0.126 \\
(0.92)\end{array}$ & & & $\begin{array}{c}-0.013 \\
(0.07)\end{array}$ \\
\hline Industrial production growth rate & & & & $\begin{array}{c}-0.369 \\
(1.65)\end{array}$ & & $\begin{array}{c}-0.328 \\
(1.59)\end{array}$ \\
\hline Dollar rate & & & & & $\begin{array}{c}0.133 \\
(0.78)\end{array}$ & $\begin{array}{c}0.003 \\
(0.018)\end{array}$ \\
\hline Intercept term & $\begin{array}{c}0.002 \\
(0.48)\end{array}$ & $\begin{array}{c}0.008 \\
(1.70)\end{array}$ & $\begin{array}{l}0.003 \\
0.42)\end{array}$ & $\begin{array}{c}0.008 \\
(1.92)\end{array}$ & $\begin{array}{c}0.007 \\
(1.64)\end{array}$ & $\begin{array}{c}0.003 \\
(0.30)\end{array}$ \\
\hline (Adj.) R-sqr. & 0.21 & 0.00 & 0.01 & 0.02 & 0.01 & 0.19 \\
\hline
\end{tabular}

Univariate and multivariate regression where the stock return of the central bank is used as the dependent variable. Monthly data for the period 1991-2000 are used. A few observations of industrial production series are not available. The estimated regression coefficient is first mentioned beneath which the absolute value of the $\mathrm{t}$-statistic is presented.

\subsection{Monthly analysis}

We now perform an analysis using monthly data to investigate the determinants of central bank stock returns. The period analyzed is 1991-2000 because of limitations in the availability of Japanese data. The main results are presented in Table 3. The analysis is first made for the central bank of Japan (Panel A) and then for the central bank of Belgium (Panel B). We report both univariate and multivariate regression results. We observe that the coefficient of the Japanese stock market index (NIKKEI 500) is positive and significant in model (1). ${ }^{10}$ Among other univariate regressions, only the industrial production growth rate variable is statistically significant (model 5). The discount rate and the growth rates in the money supply and gold value are not significantly related to the Bank of Japan stock returns. As mentioned earlier, the multivariate test results are more reliable. Model (6) reports the multivariate results. The stock market return variable remains positive (with a coefficient of 0.70 ) and 
Table 4

Average abnormal returns of Bank of Japan stock on monetary announcements

\begin{tabular}{|c|c|c|c|c|}
\hline \multirow[t]{2}{*}{ Day } & \multicolumn{3}{|c|}{ Interest rate } & \multirow{2}{*}{$\frac{\text { Exchangerate }}{\text { Decrease }}$} \\
\hline & Increase & Decrease & No change & \\
\hline-1 & 0.0056 & 0.0140 & 0.0088 & -0.0056 \\
\hline 0 & 0.0139 & 0.0024 & 0.0180 & 0.0224 \\
\hline+1 & 0.0158 & 0.0018 & -0.0288 & 0.0049 \\
\hline Total & 0.0353 & 0.0182 & -0.0020 & 0.0217 \\
\hline Number of events & 3 & 9 & 4 & 9 \\
\hline
\end{tabular}

The average abnormal daily stock returns of the Bank of Japan around the announcement of interest rate and exchange rate changes. The announcement dates are identified from searching the Wall Street Journal and Lexis-Nexis during the period 1991-2000. Day 0 is the announcement day, day -1 is the day before the announcement and day +1 is the day after the announcement.

statistically significant (t-value of 5.50). All other variables in the regression are statistically insignificant. These results are consistent with what we found earlier from the annual analysis of central bank of Belgium.

To further check the robustness of our regression results, we perform a monthly analysis with the Belgian data. The results presented in Table 3, Panel B, show that the stock market variable coefficient is positive and statistically significant. In model (6), the stock market return variable has a coefficient of 0.47 with a t-value of 5.21. None of the other explanatory variables are significant, either in the univariate or in the multivariate analysis. The explanatory power of the multivariate regression for NBB (0.19) is comparable with that of the BOJ (0.23). In sum, our findings regarding the determinants of stock returns of the central banks of Belgium and Japan are consistent with each other.

\subsection{Stock market reaction analysis}

We next look at the effect of Japanese monetary policy announcements on the stock price of the Bank of Japan. For 25 announcements during 1991-2000, we calculate the abnormal returns using four different Japanese stock market indices. Since the abnormal returns are qualitatively similar, we report the results for the Nikkei 500 index. The abnormal returns are analyzed for the day previous to the announcement, the day of the announcement, and the day after the announcement. Some announcements might be expected to favorably impact the stock of the Bank of Japan while other announcements might be expected to have a negative impact. In order to analyze the effects of announcements we place the announcements into various categories. Sixteen of the announcements involve interest rate changes and nine involve exchange rate changes. Taking a simple approach, we hypothesize that announcements of increases in interest rate will reduce the stock price and that announcements of decreases in interest rates will increase the stock price. Decreasing the value of the currency should increase the stock price if we consider the effect on Japanese trade and decrease the stock price if we consider the value of Japanese assets.

In Table 4 we present the residuals for each of the three days for the three possible interest rate movements and for the reduction in the value of the yen. Note that the stock increases 
an average of $3.53 \%$ for the three-day period for the events where interest rates increase or are supposed to increase in the future. This is contrary to what one usually expects. For the events where an interest rate decrease is announced, there is on average a $1.82 \%$ increase in the stock price. This is as expected. For the events where no clear interest rate movement is announced, the stock price change is a small decrease of $0.2 \%$. For the nine announcements indicating that the Japanese currency would decrease in value, the stock price increases on average by $2.17 \%$.

We tested whether the three-day cumulative average excess returns were statistically significant for each of these four groups of events. None were significant at the five percent level, with the $\mathrm{t}$ values being 1.35 (interest rate increases), 1.20 (interest rate decreases), -0.09 (interest rate unchanged), and 1.44 (exchange rate decrease). These results are consistent with our regression results where we did not find statistically significant relationships with macroeconomic variables. Macroeconomic announcements seem to slightly affect central bank stock returns, but the magnitude is not statistically significant.

We also analyze a few miscellaneous types of announcements. The most noteworthy of the abnormal returns for these events was a $6.18 \%$ increase (with at value of 2.36) when it was announced that the Bank of Japan was the most profitable entity in Japan and a $6.64 \%$ decrease (with a t value of -2.54) decrease when the Bank of Japan was given more control over interest rates. The second event, as discussed above, resulted in more independence of the BOJ from the Ministry of Finance and perhaps the market had more faith in the ability of the Ministry of Finance with respect to monetary policy. We tested for the statistical significance of the excess returns for all events and found a few to be significant. Since there was no consistent pattern of significance we do not present the results here, but they are available from the authors.

\section{Conclusions}

The common stock of the central banks of Belgium and Japan are publicly traded, unlike most other central banks. This is an interesting case by itself; it opens the possibility that the capital market can monitor a government agency.

We trace historical stock market performance of the central banks of Belgium and Japan. We find that the stock return of the Belgian central bank has been under-performing over the past few decades. We also find similar underperformance for the Japanese central bank during the last few years. Overall, our results indicate that shareholders of the central bank could have earned higher returns had they invested their capital in the stock market index. Underperformance of central bank stock exists on a risk-adjusted basis too.

Efforts to explain central bank stock performance have met with limited success. But, this is not unusual. It is very difficult, if not impossible, to find statistically significant determinants of stock returns of a single firm. We use a long time-period with annual data and a relatively short time-period with monthly data to investigate the determinants of the stock return of the central banks of Belgium and Japan. Our results show that the only factor that significantly explains changes in central bank stock returns is the market return. Some macroeconomic variables like the unemployment rate, the dollar exchange rate, and the 
growth in industrial production show some significant relationship, but only in a univariate context. In the multivariate analysis, neither the assets of the central bank nor the macroeconomic factors are significant determinants of central bank stock returns. Overall, our results for both central banks are quite similar. An event study of some Japanese macroeconomic announcements also indicates that there is no statistically significant change in the value of the central bank stock.

This work could perhaps be extended to other countries with a central bank or any other (semi)governmental institution that is publicly traded in order to determine why these countries have chosen this organizational arrangement. This paper indicates that it is possible to have a central bank that is owned by the public.

\section{Notes}

1. The historical information was collected from diverse sources including Contant (1910), Eizenga (1994), Kauch (1950) and Van der Wee and Tavernier (1975).

2. This kind of establishment was a common feature at that time. The Bank of England, founded in 1694, was a commercial bank with its stock held by the King, the Queen and several hundred individuals.

3. This discussion is drawn from Cargill et al. (1997) and Patrick (1992).

4. Information was obtained in phone conversations with a representative of the Bank of Japan in New York.

5. We are grateful to Andre Farber for providing us the historical series of Belgian stock market index which was adjusted for dividends.

6. We could not obtain a monthly series of gold reserves value for the central bank of Belgium.

7. Lexis Nexis contained announcements from the Financial Times, the New York Times, the Journal of Commerce, and the Los Angeles Times.

8. Unofficial trading of stocks and bonds during these years took place in cafés and a dancing floor near the Stock Exchange (De Clercq, 1992).

9. We do not present the results here, but they are available from the authors upon request.

10. Three other stock market indices are also used with qualitatively similar results.

\section{Acknowledgments}

We thank several officials of the National Bank of Belgium including Marcel van Campen, Christian Dekeyser and Michel Dombrecht for their kind co-operation. We offer special thanks to Daisy Dillens without whose help many of the historical data collection would have been impossible. We also thank Linda Allen, Steven Ongena, Martin van Tuijl, and seminar participants at the National Bank of Belgium and the Federal Reserve Bank of Atlanta for many helpful comments. All remaining errors are our responsibility. 


\section{References}

Cargill, T., Hutchison, M., \& Ito, T. (1997). The Political Economy of Japanese Monetary Policy. Cambridge, MA: The MIT Press.

Conant, C. (1910). The National Bank of Belgium. National Monetary Commission, Washington, pp. 238.

De Clercq, G. (1992). On the Exchange: History of stock trading in Belgium 1300-1990 (in Dutch), ed., Marc Van de Wiele Publishers, Brugge, pp. 480.

Eizenga, W. (1994). The National Bank of Belgium and monetary policy, SUERF Papers on Monetary Policy and Financial Systems, No. 17.

Goodhart, C. (1991). The Evolution of Central Banks. Cambridge, MA: The MIT Press.

Kauch, P. (1950). The National Bank of Belgium: 1850-1918 (in Dutch), The National Bank of Belgium, pp. 458.

Patrick, H. (1962). Monetary Policy and Central Banking in Japan, University of Bombay, Series in Monetary and International Economics, No. 5.

Van der Wee, H. \& Tavernier, K. (1975). The National Bank of Belgium and the monetary events between the two world wars (in Dutch), The National Bank of Belgium, pp. 548. 